\title{
A.O.U. Meeting, Regina, August 25-30
}

All members of the S.N.H.S. seriously interested in birds are reminded that the feature of 1959 will be the meeting of the American Ornithologists' Union in Regina, August 25-30.

\section{PLACE:}

Saskatchewan Museum of Natural History.

\section{PROGRAMME:}

Tuesday, August 25: Registration (afternoon and evening); business meetings (Council Members, Fellows, Elective Members only); Museum Open House 7:00-10:00 p.m. (films at 8:00, informal reception at 9:00).

Wednesday, August 26: Registration (all day); papers sessions (all day); tour to Fort Qu'Appelle for wives of delegates 1:00 p.m.; opening of Canadian bird art and Museum bird photo exhibits; exhibits reception, Norman Mackenzie Art Gallery, 8:15 p.m.

Thursday, August 27: Registration (all day); papers sessions (all day); picnic supper Wascana Park 6.30 p.m.; film programme at Museum 8:30 p.m.
Friday, August 28: Papers sessions (all day); annual banquet 6:30 p.m.

Saturday, August 29: All-day field trip to north end of Last Mountain Lake, buses leaving Regina College at 7:00 a.m.

Sunday, August 30: Additional local field trip.

All activities (except the business meetings) are open to non A.O.U. members. There will be a registration fee of $\$ 2.00$, and an activities fee of $\$ 3.00$ (covering banquet, receptions at Museum and Art Gallery, field trips, etc.). The local A.O.U. committee hopes to have certain funds to assist student ornithologists and serious young amateur bird students to come from various parts of Canada to the Regina meeting. Chairman of the Students Grants Committee is Joyce Dew, Saskatchewan Museum of Natural History, Regina.

Further information about the programme is available in the A.O.U. circular of information which will be mailed upon request from the Museum.

\section{Co-operative Bird Migration Study}

For the past six years, hundreds of observers have been co-operating in a continent-wide study of the spring migration of a selected list of species of birds, carried out under the auspices of the U.S.A. Fish and Wildlife Service. This year the Blue Jay is again participating in the study, and members are asked to submit the records that they have been keeping of the 1959 spring migration. You will remember that information is requested on first seen dates and if possible dates of peak migration and final departure. The forty species on which information is desired this year are:
Whistling Swan
Catbird
Canada Goose
Brown Thrasher
Mallard
Pintail
Marsh Hawk
Killdeer
Common Snipe
Mourning Dove
Common Nighthawk
Chimney Swift
Ruby-throated Hummingbird
Wood Thrush
Eastern Bluebird (male)
Yellow-shafted Flicker
Eastern Kingbird
Great Crested Flycatcher
Eastern Phoebe
Eastern Bluebird (female)
Red-eyed Vireo
Black-and-white Warbler
Yellow Warbler
Myrtle Warbler
Ovenbird
American Redstart
Red-winged Blackbird
Baltimore Oriole
Scarlet Tanager
Rose-breasted Grosbeak
Eastern Wood Peewee
Indigo Bunting
Barn Swallow
American Goldfinch
Purple Martin
Slate-colored Junco
Common Crow
Chipping Sparrow
House Wren 